\title{
Café e educação no século XIX*
}

\author{
Denise A. Soares de Moura**
}

\begin{abstract}
RESUMO: Propostas educativas ocuparam cafeicultores e autoridades municipais, provinciais e policiais na segunda metade do século XIX. Com a crise nas relações escravistas, insistiam na necessidade de se educar as camadas sociais pobres e livres, os ingênuos, os forros e libertos para o trabalho, mas aquele se firmava sob as exigências da economia cafeeira. A preocupação maior se deu com as crianças, com os pobres e escravos, propondo-se a criação de escolas agrícolas para educá-las no trabalho disciplinado nas grandes propriedades. As tensões, os limites e as conseqüências desse movimento para as relações sociais e humanas são discutidos neste texto.
\end{abstract}

Palavras-chave: Sociedade cafeeira, educação agrícola, escravidão, relações sociais, trabalho

Conta-se no fabulário popular brasileiro que uma velha tinha um filho tão preguiçoso, que sua vida era comer e dormir. Certo dia, contrariada com sua ociosidade, deu-lhe umas boas relhadas, obrigando-o a sair de casa para trabalhar, de modo a ganhar quanto fosse possível.

No caminho, sem ânimo para fazer coisa alguma e sentindo sede, o moço sentou-se à beira de um riacho e, colocando a mão dentro do riozinho, pegou um peixinho ainda agitado. Ameaçou colocá-lo no bolso, mas o peixinho, mais que depressa, disse-lhe que, se não o matasse, Ihe daria o que pedisse, desde que dissesse sempre: "Querendo Deus e o meu peixinho..."

* Agradeço a Guita e Sr. José Mindlin pelo permissão de acesso e consulta à sua biblioteca, e às suas bibliotecárias Cristina Antunes, Elisa e à amiga Rosana Gonçalves.

* * Doutoranda no Departamento de História da Faculdade de Filosofia, Letras e Ciências Humanas (FFLCH) da Universidade de São Paulo (USP) e bolsista da Fapesp. E-mail: dmsoa@bol.com.br 
O moço, então, jogou-o na água e, desejando arranjar um feixe de lenha para levar à sua mãe, resolveu experimentar a promessa do peixinho. Invocando-o, rapidamente apareceu diante dele, e sem esforço algum, um enorme feixe de lenha, mas tendo preguiça de carregá-lo, novamente recorreu ao dito do peixinho, que fez com que o próprio feixe o levasse.

Ao passarem em frente ao palácio do rei, a princesa e suas criadas acharam graça na cena que viram, rindo muito do preguiçoso. Indignado, este pediu ao peixinho que fizesse a princesa ter um filho seu.

Chegando em casa, entregou o feixe à mãe e voltou à vida de preguiça, pedindo tudo ao peixinho. No palácio, com o correr dos dias, a princesa começou a sentir-se muito mal, chegando ao conhecimento de todos que esperava uma criança.

O rei, muito furioso, assim que the nasceu o neto, ordenou que todos os homens do reino fossem reunidos no pátio do palácio para descobrir quem era o pai. A princesa passou com a criança perto de cada um e esta abriu os bracinhos diante do preguiçoso.

Rancoroso, o rei trancou os três numa caixa e soltou-a ao mar. Por um bom tempo viveram assim, dando-lhes de tudo o peixinho, até o dia em que o preguiçoso resolveu pedir-Ihe um belo e rico palácio.

Imediatamente se viram dentro de um castelo de grande formosura e riqueza, com criados, carruagem, louçaria e mobília majestosa. O preguiçoso tornou-se príncipe, vivendo todos muito felizes e com muita riqueza.

O rei aos poucos ia sendo corroído pelo remorso do arrenego de sua filha e de seu neto. Quase não dormia, sofrendo em vigílias de arrependimento. Numas dessas noites avistou o belo palácio e resolveu visitá-lo.

Foi muito bem recebido pelo preguiçoso com uma farta e variada mesa de jantar, não o reconhecendo. A certa altura, o rapaz pediu ao peixinho que fizesse aparecer no bolso do rei uma colher de ouro.

$\mathrm{Na}$ despedida, deixou-a cair ao chão, gaguejando de constrangimento e perguntando como poderia ser ladrão sem saber. O preguiçoso respondeu: da mesma forma que sua filha foi mãe sem querer. O rei aprendeu a lição, abençoando sua filha e seu neto, passando a viver todos juntos no majestoso palácio, com muita felicidade e fartura.

$\mathrm{Na}$ cultura brasileira, o desejo de riquezas e posições alcançadas com facilidade, de titulações e de prosperidade sem esforço, como no exemplo do 
próspero preguiçoso dessa fábula do norte, aparece em histórias e personagens que avançaram gerações. É compreensível uma figura como a de Pedro Malasartes num meio formado pela influência de um povo que negava honra e valor social a alguém enquanto vivesse de trabalhos mecânicos.

Burlão invencível, astucioso, cínico, incansável em embustes contra ricos, avarentos, orgulhosos, vaidosos, Malasartes é um tipo tradicional nos contos populares ibéricos, aclimatado nos trópicos, numa espécie de culto à malandragem e à esperteza, tanto quanto à vida que se passa em ócio, em ajustes e trapaças, nunca em trabalho aturado.

O senso comum firmou e difundiu a imagem de que brasileiro não gosta de trabalhar e adora feriado. Se ainda é muito acentuada, no exterior, a associação de futebol, sol escaldante, praias e mulheres bronzeadas com Brasil, ou seja, uma ênfase no não-trabalho, em nossas plagas não é raro deparar com falas, em tom de brincadeira ou não, que referendam um pretenso gosto pelo ócio.

Já nos tempos da colonização do país, na então América Portuguesa, o português trouxe consigo a noção de trabalho como algo desonroso. Presunçosos de uma fidalguia requerida por costumes ancestrais, repugnavaIhes qualquer moral fundada no culto ao trabalho. Nobre e honrado era aquele que tinha alguém para trabalhar por si. Uma maneira de conceber em desacordo com a ética protestante que tomava fôlego com a expansão capitalista.

Assim, couberam ao braço índio, na colônia, a indústria extrativa, a caça, a pesca e certos ofícios mecânicos, satisfazendo, dessa forma, interesses econômicos iniciais do colonizador, até os homens e mulheres de África mostrarem-se comercialmente mais vantajosos e aportarem às centenas no litoral nordestino, deixando os negros da terra - como eram chamados os indígenas pelos portugueses - para as cobiças de paulistas e jesuítas.

Muito se falou no quanto a escravidão negra desqualificou o exercício do trabalho manual na cultura brasileira, mas uma ética do trabalho, ao modo dos protestantes, inexistiu entre os habitantes da Península Ibérica. Foram antes sonhadores quixotescos de feitos heróicos que lhes trouxessem honraria, sem que precisassem erguer um machado.

O certo é que a possibilidade da fidalguia e da ociosidade se restringiu àqueles, bem ou mal, favorecidos pela fortuna de ter pelo menos um escravo para lidar por si. Para a maioria, pobre e livre, necessitada de ganhar a vida por 
esforço próprio, a nobiliarquia e o ócio foram intenções impossíveis de praticar, se algum dia os desejou de fato.

O fabulário popular metaforizaria esse traço cultural trazido pelos colonizadores portugueses, em sapos que viravam príncipes, moças órfãs que se tornavam princesas e peixes mágicos que livravam seus agraciados do fardo do trabalho.

Entre gente hispânica e lusa, colonizadora de novas terras que alcançaram, não vingaram a liturgia do trabalho e a atividade utilitária. A profecia divina dos primórdios do mundo, de que se ganharia o pão com o suor do próprio rosto, quase não encontrou eco entre povo tão religioso e católico, parecendo atraente e mais nobilitante a "digna ociosidade" (Holanda 1991, p. 10).

Vaidosas de não calejarem as mãos no arado ou na enxada, gerações de descendentes dos conquistadores assistiram, sem inquietações previdentes, à fragmentação de suas terras e riquezas, ao longo do século XIX. Muitos acaipiraram-se e passaram a viver do trabalho da roça, como Apolinário Leme, filho de um dos desbravadores das terras da atual região de Campinas, grande potentado do século XVIII, sempre perdoado em seus crimes por El-Rei de Portugal e adulado por capitão-general e ouvidor.

Surpreendia-se um escritor do Dezenove com um feitor da fazenda de um seu vizinho, "neto legítimo d'um barão", um fidalgo que fora tão rico, que erguera uma capela que valia centenas de contos, mas que nada tinha para educar seus netos. Na história dos colonizadores brasileiros, muito orgulho de títulos nobiliárquicos e patentes militares deu lugar à modéstia de estalajadeiros, taberneiros e feitores da descendência desses potentados. ${ }^{2}$

Mesmo em desacordo com as condições e exigências do tempo, cresceram os filhos dos conquistadores sob os auspícios da descendência de tal sargento-mor ou de ser sobrinho de tal brigadeiro. Não foram os referenciais do trabalho como meio de ganhar a vida que lhes orientaram o rumo a seguir, mas o orgulho das filiações, que terminou por traçar para uns a decadência, para outros, um prestígio que correspondia mais ao sobrenome que às posses.

Essa importância da ligação familiar permanece ainda hoje na sociedade brasileira, de forma que o valor de uma pessoa muitas vezes é medido mais por suas vinculações familiares, do que pelas idéias que defenda ou pelo grupo a que pertença.

As decisões do governo da mãe-pátria, no período colonial, viriam dificultar qualquer desenvolvimento de uma ética do trabalho, como a recompensa 
atribuída por D. João IV à fidelidade dos potentados do Grão-Pará e do Maranhão, durante a guerra contra os holandeses, dando-Ihes prerrogativas de nobreza. Diz-se que muitas confrarias formadas por artífices das últimas classes extinguiram-se, por terem enobrecido boa parte de seus membros, que se recusavam, por isso, a exercer ofício (Souza 1875, pp. 69-70).

A proibição de criar indústrias no país impediu a fermentação de condições favoráveis para o desenvolvimento de ofícios urbanos. A indústria doméstica apenas latejou em alguns pontos do país, e mesmo sua liberação pelo alvará de $1^{\circ}$ de abril de 1808 não traria alterações significativas nesse quadro. Tais medidas impediram que iniciativas de trabalho urbano e industrial, mesmo que doméstico, ganhassem vitalidade.

Tome-se o caso das corporações de ofício, que não encontraram terreno fértil para prosperar. Poucos foram os grêmios de mestres e escrivães de ofício, sob a tutela das câmaras municipais. Viviam envolvidos com atos religiosos, como as festas anuais a seus santos protetores (Holanda 1993, p. 27) e as festas oficiais da família real. No mais, como esperar que ganhassem viço associações de trabalhadores, num meio em que qualquer senhor de escravo costumava empregar seus negros em serviços, negociando depois o produto de seu trabalho? (idem, p. 26).

O cativeiro viria somar-se a essas condições que dificultaram o desenvolvimento de uma ética do trabalho, aviltando-o e associando-o aos sofrimentos do eito. A intenção da ociosidade encontrou, assim, condições para fermentar entre pessoas de várias classes sociais, por meio dos escravos, que eram colocados para trabalhar para elas, fossem quantos fossem, nas ruas da cidade ou nas lavouras, e por meio das histórias que alimentavam a imaginação popular.

A ociosidade enobrecia e heroicizava seus personagens. Na psicologia ibérica, formadora de nossa própria, nos tempos da colonização, há que se levar em conta que o ócio sempre contou mais que o negócio, de forma que a atividade produtora era menos valorosa que a contemplação e o amor (Holanda 1991, p. 10).

O avanço do capitalismo industrial na Europa e o estabelecimento da corte portuguesa no país forçariam mudanças de atitude e concepção em relação ao trabalho, embora apenas insinuadas de início. As condições do tempo exigiriam que o trabalho se tornasse prova de honestidade, enfatizando suas possibilidades de sustento, de dar dignidade, de possibilitar poupança e a necessidade de se educar um povo que a então elite cafeeira considerava tão sem costume de sujar e calejar as mãos na faina diária com a terra. 
Um povo que, se atentarmos com rigor, ao longo da história do Brasil, envergou suas costas no amanho incansável da terra, engrossou as mãos no trançamento de cipós para compor cestaria, pôs a vida constantemente em fio, ao atravessar rios e barrancos escorregadios. Certo contemporâneo reconheceu que essa gente arrancava, "com o suor do seu rosto, seus meios de subsistência, lutando ao mesmo tempo com todos os encargos" da Guarda Nacional e policial que the pesava. ${ }^{3}$

Quanto à necessidade de educação para o trabalho, que tanto se apregoou e defendeu com o advento da era da ferrovia e do vapor, nela não se incluíam os filhos das camadas dominantes. Não, essa necessidade não se estendia a eles.

Nesses anos, o bacharelismo e a vida política surgiriam como solução viável para a perpetuação de honrarias e títulos. Ao lado dos barões, emergia e fincava pé o bacharel, senhor de letras, muitos não tanto pelo trabalho mental aturado e fatigante, mas por bem falar e vestir.

Com uma economia fundada nos quadros do mundo agrário, dos engenhos canavieiros do nordeste, que prosseguiria nas fazendas cafeeiras do sudeste, foi para o trabalho agrícola que se voltaram os senhores da política. 1808 inaugurou o compromisso transitório das elites, e uma de suas tarefas seria introduzir um culto à ética do trabalho no país, pois era preciso que o trabalho deixasse de ser algo aviltante da condição humana a desonrar aquele que o exercesse.

A elite cafeeira ergueu, assim, uma nova escala de valores para se pensar o trabalho manual e agrícola. Isso não deixa de indicar mudança de ação e pensamento entre homens que herdaram de seus avós repugnância a toda moral fundada no trabalho manual.

Uma ética do trabalho passou a ganhar terreno nas preocupações dos dirigentes políticos e econômicos. Mas o autêntico apreço ao trabalho e à atividade utilitária ainda passaria muito longe desses homens e de seus filhos, cultores do bacharelismo e do empreguismo público, da vida de homens da política. A gente do povo que se perpetuasse em lides exaustivas e intermináveis. Era preciso valorizar o trabalho para essa gente, de modo a fazerem uso do seu potencial de trabalho, canalizando-o para interesses agrários e até como uma maneira de conter o risco potencial de criminalidade e anarquia que sempre acreditaram que a camada popular contivesse.

A supressão do escravismo no país, um dos grandes impedimentos para a plena valorização do trabalho, foi um processo tortuoso, levado adiante 
sob a combinação da rebeldia escrava com medidas dilatatórias promovidas pelas elites que indicavam o temor dos dirigentes do país pelas soluções radicais e suas conseqüências catastróficas. ${ }^{4}$ Foi da índole política do Império não querer precipitar medidas arrojadas que pudessem pôr em xeque quadros de estabilidade duramente conquistados, enfrentando e sufocando as rebeldias da regência (Holanda, vol. 5, p. 284).

As condições que inauguraram o século XIX - a revolução industrial européia, mas muito mais inglesa, o avanço das idéias liberais, o processo de emancipação política das colônias da América - forçariam o desajuste de esquemas tradicionais.

Para os ingleses, grandes protagonistas dessa fase de expansão do capitalismo, os escravos coloniais mostrar-se-iam como um entrave ao crescimento dos mercados e à modernização dos métodos de produção. As ressonâncias desse processo no Brasil seriam feitas sob pressões britânicas para a extinção do tráfico negreiro e sob o surgimento dos primeiros germes de fragilização do sistema escravista.

A rede de dependência e influência urdida pelo apoio dado pelos ingleses à família real em fuga, em 1808 e posteriormente, na emancipação política do país, precipitaria os primeiros sinais da crise desse sistema.

A ação repressiva britânica dirigiu-se, assim, para o abastecedouro de mão-de-obra, ou seja, o tráfico internacional, impondo às potências escravistas a assinatura de sucessivos tratados, progressivamente mais exigentes.

Primeiramente, sua ação policial nos mares, por volta de 1810, limitouse a restringir as áreas de tráfico lícito, para posteriormente impor a admissão de visita e busca em navios suspeitos de comércio negreiro ilícito e estipular um prazo para o fim do vil comércio humano; por fim, dispensou a prova da presença efetiva de africanos nos navios, contentando-se com evidências indiretas que caracterizassem a atividade negreira de uma embarcação.

Firmada a independência, o Brasil passou a ser pressionado pela Inglaterra para concordar com a assinatura de um tratado que definisse um tempo curto para a extinção do tráfico negreiro (Holanda, vol. 3, p. 189).

A habilidade protelatória das elites dirigentes da época mostrar-se-ia no encaminhamento que deu à questão, combinando projetos, tratados, leis e decretos que se revelariam inócuos. Vertiginosa foi a entrada de escravos no país, nesses anos de ludíbrios às pressões inglesas (Holanda 1991, p. 44 e Holanda, vol. 3, pp. 189-196). 
Mesmo a Bill Abeerden não iria conter a sangria d'África e a sanha dos traficantes brasileiros, doutos em sinais costeiros que alertavam para a presença dos agentes fiscalizadores britânicos. Um romance paulista retratou a amizade desses traficantes com as autoridades; hábeis em iludi-las, eles traficavam à vontade, sem que elas de nada desconfiassem (Castro 1861).

É provável que tais autoridades fizessem vistas grossas a muito do que viam, amarradas que estavam a vinculações de família, parentescos fictícios e a uma ética de favores com a qual sempre podiam, reciprocamente, contar. Perseguições políticas, policiais e suborno a funcionários funcionavam como estratégias da garantia de impunidade. Isso fez com que mesmo após a Bill Abeerden, o comércio cativo vivesse ampla vitalidade (Holanda 1991, p. 43).

Por essa lei, de 8 de agosto de 1845, obra de ingleses, a contragosto do governo imperial, a Inglaterra passava a legislar para o Brasil na questão do tráfico, tendo pleno direito de apreender, julgar e punir toda a embarcação negreira do país, capturada em todos os mares pelos navios britânicos.

O golpe definitivo no tráfico negreiro viria somente em 1850 , com a lei Euzébio de Queiróz, concebida em meio a ressentimentos partidários, mais do que por autêntica bandeira política. Essa lei iria alertar senhores de escravos e elite dirigente sobre a necessidade de ação mais efetiva e precisa no encaminhamento do problema da transição para o trabalho livre, dilatando até onde não mais pudesse sua solução.

No curso conciliatório da política imperial, o momento mais agudo do problema da supressão do tráfico coincidiu com o ostracismo dos liberais, dando-Ihes, na oposição aos conservadores que ascendiam ao poder, a oportunidade de criar um programa reivindicatório em torno dessa questão. Assim, o Partido Liberal, que comungou com o Partido Conservador a manutenção do tráfico, reprimiu-o, nesse momento, como proposta partidária que justificava seu retorno ao poder (Holanda, vol. 3, pp. 198-199).

As elites dirigentes do país expressariam muito bem, na longa trajetória do fim do tráfico, suas tendências para ações ponderadas e cautelosas, que tanto impregnariam o próprio compromisso transitório da abolição do escravismo.

Proibir a entrada de negros cativos no país significava áspero golpe na base das relações de trabalho. Mas também quebra do status quo e de uma estrutura política e econômica há muito assentada. 
Assim, senhores empertigados e desconfiados das mudanças que se anunciavam com a vinda da corte se mobilizaram em relação ao angustiante problema dos braços para a lavoura, por meio de um compromisso político, visando a apaziguar o mais que pudessem os efeitos da transição do escravismo para o trabalho livre.

Para tanto, ocuparam as tribunas das Assembléias Legislativas, os editoriais dos jornais, os teatros e mesmo reuniram-se por conta própria, para discutir à exaustão como resolver o problema da libertação dos escravos, o que fazer com os libertos e os ingênuos, ${ }^{5}$ com a população livre e pobre do país, como promover a formação de uma ética do trabalho, que respondesse aos interesses do tempo, ou seja, dos cafeicultores do sudeste e suas lavouras.

Ciosas de atenuações e de sentirem-se senhoras de situações que anunciavam mudanças de status quo e da ordem estabelecida, nossas elites dirigentes envolveram-se nesses debates intermináveis como estratégia do compromisso transitório que assumiam. Era uma maneira de protelar e amaciar quadros de incerteza, dar tempo ao tempo para que as novas condições se estabelecessem quando já não mais trouxessem riscos a posições, privilégios e poderes há muito enraizados.

A idéia da "educação para o trabalho", amplamente discutida nesses anos por senhores de terras e escravos, dirigentes políticos e pessoas de algum modo vinculadas ao mundo cafeeiro de então, foi um dos pilares do compromisso estabelecido, procurando reajustar noções de trabalho existentes às exigências do tempo, de modo que quando não fosse mais possível manter os escravos assenzalados, os ritmos intensos de trabalho nas emergentes lavouras cafeeiras paulistas se mantivessem.

As camadas dirigentes e os fazendeiros tinham conhecimento da população que vivia no país. ${ }^{6}$ Contavam com seu potencial de trabalho. Invocavam-na nas acaloradas discussões políticas: "Não temos propriamente no paiz falta de braços. Esta proposição é fácil de demonstrar; é questão de estatística"; "com taes dados chega-se facilmente a conclusão de que o número de braços existentes naquella provincia - São Paulo basta para manter e augmentar a producção actual do café" (Congresso Agrícola 1878, pp. 169-170).

Mas era sob a orientação dos referenciais de sua época e das tendências que professavam, que definiam os modos de vida dessa população, de forma que quase nenhuma propensão tiveram em conceber como trabalho as atividades com as quais se envolviam. Dizia, a elite cafeeira, 
que muito pouco faziam, indo aos domingos à cidade, às vilas ou freguesias, comprar pólvora e chumbo para caçadas, das quais tiravam seu sustento, passando "dias a jogar e a tocar uma violinha".

Costumavam também criminalizar as formas de ganho dessa população. Lamentavam não poder processar pessoas pela "razão illusoria de... terem uma occupação". Questionavam, indignados: "Como formar processo a um cidadão, que está no seu sítio, no seu rancho, na sua choça, na sua toca, afiando um machado, a quem declara, que se está preparando para o trabalho?"

Educar, para as elites, era uma maneira de inserir essas pessoas na disciplina de trabalho que professavam, modificando, com isso, formas próprias de prestar serviços e trabalhar. Tarefa que se impôs a custo, ao longo de décadas de história, sem eliminar de todo as resistências.

Basta pensar nas persistências dos pequenos plantadores das comunidades rurais do passado, embora dando novas direções a antigos modos de vida e convívio social. A duras penas, mas ainda vivos, é possível ouvir os ecos dos sapateados dos moçambiques e cateretês, da cantoria das congadas, dos murmúrios das rezas das novenas, do farfalhar das roupas em andanças de negócios para ganhar a vida pelas cidades do interior do Brasil. ${ }^{9}$

Nas grandes cidades, no trabalho informal das ruas, são jeitos ancestrais de negociar que ainda pulsam, confundindo e contrastando pregões, ligações de amizade e parentesco, a medida do tempo dada pelo momento da alimentação com o que a tecnologia digital vem oferecendo de mais avançado.

Em meados do século $\mathrm{XIX}$, vivia-se sob o avanço do capitalismo industrial europeu, que nutriu e era nutrido por idéias como razão, ciência, progresso e liberalismo. O capitalismo se difundia sob a liderança inglesa, e uma minoria de países transformava-se em economia industrial (Hobsbawm 1979, pp. 22 e 49-52).

Países da América Latina acomodar-se-iam à nova ordem como fornecedores do que saísse de suas entranhas e se mostrasse rentável para o mercado externo. No Brasil, o café avançaria com voracidade, fértil e destruidora, nas terras de Minas Gerais, no sul fluminense e no Vale do Paraíba, coincidindo sua chegada ao oeste paulista com o fim do tráfico negreiro. Uma economia do café, era o Brasil, e, sob a tônica de seu tempo, curvou-se, reverenciosamente, à riqueza e ao progresso que emanassem das transações com esse gênero. 
As sociedades, cada qual a seu modo, subordinaram-se a todas as formas de atividade intelectual, à ciência em particular, apoiada nas duas principais correntes filosóficas do período: o positivismo francês e o empirismo inglês.

A metáfora básica do mundo de orientação burguesa, sob inspiração do evolucionismo darwinista, era a de que somente "os mais capazes" sobreviveriam, sendo, portanto, necessário tornar as pessoas capazes para algo, principalmente "algo" que atendesse às ambições de progresso e fortuna de uma minoria privilegiada. Por isso a educação surgia como possibilidade de "capacitar", mas para os interesses de uma época (Hobsbawm 1979, p. 135).

Brasileiros cultos envolvidos com os interesses agrícolas cafeeiros viram no progresso a promessa da perfeição social e do desenvolvimento econômico, de forma que, a partir dos anos 70, o positivismo de Auguste Comte penetrou com força no país, referendando essa intenção.

Mas para que o progresso triunfasse era preciso renunciar ao passado e à tradição, tidos como atraso. A "educação para o trabalho", como ciência reformadora, vinha mudar antigos costumes dos trabalhadores, de modo a ajustá-los à sociedade capitalista civilizada, já que, como se escrevia na época, era preciso "regenerar... parte da sociedade moderna... coberta de chagas, ainda devorada das úlceras" legadas do passado (Souza 1875, p. 68).

Muito modo de reunião do povo - cateretês -, de trabalhar - ceifar a roça de alimentos, negociar com as criações, carpintaria -, de cantar - moda de viola caipira -, e muita história contada ao pé do fogo - curupira, boitatá, saci - estiveram sob as pressões das intenções civilizatórias, com vistas ao progresso, quase fazendo-as render-se de todo.

Uma das tônicas da época tendia para a educação como superação, considerando-se que as formas de expressão e vida que escapassem aos referenciais de progresso e riqueza eram arcaísmos que deveriam ser reformados e reajustados às invocações do tempo.

Imiscuindo-se nesse campo, os fazendeiros do sudeste, reunidos no Congresso Agrícola de $1878,{ }^{10}$ mostrar-se-iam zelosos da instrução da população, mas se na Europa o ensino era feito como possibilidade de criar operários, nas terras do Brasil cobiçavam-se principalmente lavradores.

Distraídos dos ritmos dos sítios e dos trabalhadores urbanos e rurais pobres, preocupava-os a reorganização do trabalho agrícola, algo fundamental para o encaminhamento mais conveniente da transição. O objetivo era criar 
estabelecimentos de instrução principalmente agrícola, em todas as comarcas rurais que fosse possível, cuidando-se para não produzir sábios enfatuados, mas homens de pés no chão e práticos, ensinando-Ihes mexer com máquinas, mas aquelas que beneficiassem melhor o café (Congresso Agrícola 1878, pp. 31-35).

Apostavam na fundação de escolas-fazendas, que receberiam os ingênuos e os órfãos, pois entendiam que se abandonassem a educação daquelas crianças, isso poderia trazer em breve perturbação na organização do trabalho, e educá-las nesses estabelecimentos seria uma maneira de torná-las úteis (Congresso Agrícola 1878, p. 38), pois poderiam aprender a manusear e dirigir os instrumentos aratórios, executar com os braços as operações agrícolas, pensar e curar com as mãos os animais domésticos (Souza 1875, p. 101).

Fez parte, então, do compromisso transitório, que senhores da terra se envolvessem com questões de educação, prevenindo-se, dessa forma, contra perturbações que, acreditavam, a abolição poderia trazer. Tornar úteis ingênuos e órfãos, como entendiam as elites cafeeiras, era, senão suprimir, pelo menos atenuar quadros de instabilidade social. A educação agrícola assumia caráter de utilidade no contexto transitório.

As tendências ponderadas dos senhores de café revelar-se-iam mais duramente com relação aos ingênuos, segmento que mais os aproximou, no curso do compromisso transitório, da realidade futura de se conviver com a população negra fora dos referenciais da escravidão.

A crise de braços anunciada com a extinção do tráfico negreiro fazia-os investir na possibilidade do trabalho dos ingênuos nas propriedades, conforme educação adequada, pelo menos enquanto se mostrasse incerta e confusa a viabilidade do braço estrangeiro."

Pelo menos, a educação agrícola nas escolas primárias obrigaria os ingênuos ao trabalho, habilitando-os a isso, e quando chegassem aos 21 anos - idade que ressaltava as apreensões e prevenções dos cafeicultores -,deveriam ser inscritos no "corpo de lavradores", cabendo a seus diretores e inspetores auxiliares fiscalizar suas condutas (Congresso Agrícola 1878, pp. 40-45).

Explicavelmente inspiradas nas "nações civilizadas da Europa", as elites preocupavam-se com as crianças pobres, mas também com todos aqueles oriundos da exclusão social, como órfãos, gente que vivia da 
mendicidade e prisioneiros. Preocupação que tinha mais em vista o controle social que humanizar suas vidas, asilando-os em "orphelinatos, pensionatos agrícolas, colônias penitenciárias” (Souza 1875, p. 86).

No município paulista de Casa Branca já vigorava, na segunda metade do XIX, uma colônia agrícola de órfãos, que evitaria, como se desejava, a formação de "homens sem préstimo e portanto inúteis à sociedade". Nela, os professores acompanhavam os alunos nos serviços da lavoura, o "que os acostuma ao trabalho", tornando-os úteis ao país.

Muitos órfãos também se ocupavam com a aprendizagem de vários ofícios, de forma que o trabalho assumia uma função preventiva do potencial criminoso e das tendências para a ociosidade que as elites viam nas crianças pobres e em todos aqueles nascidos em berços humildes.

Mesmo os filhos dos imigrantes europeus que entrariam no país às doses, ao longo do período 1850-1880, não escapavam das precauções de abrigo e instrução das elites, temerosas de que "mendigos, ratoneiros e criminosos em embryão, matéria disponível para importunar no futuro a caridade publica, povoar os adros das igrejas, atravancar as calçadas, ostentando moléstias de chumaço e indo, mais tarde, encher os recintos das prisões". Alertavam: "não vemos já nas praças e esquinas de nossas ruas esse enxame de pequenos italianos, engraxadores de botas e tocadores de rabeca, esfaimados e trescalando a álcool, passando os dias pelos botequins e estendendo a escudella da esmola à philantropia dos habitantes desta grande cidade?" (Souza 1875, p. 117). Os expedientes infantis da sobrevivência, forjados nos embustes imprescindíveis da cultura da rua, apareciam como sinais de criminalidade, que esperavam conter entre muros de asilos e colônias.

Muitas das sociedades filantrópicas que surgiram com a expansão da sociedade burguesa e industrial trilhavam essa finalidade. João Henrique Pestallozzi foi pioneiro, tendo em 1775 fundado a primeira colônia agrícola em Argóvia, um dos cantões da Suíça. Foi o germe do pensamento civilizador dos asilos que ganharia força na era do vapor, do ferro e da ferrovia.

Mesmo em São Paulo, nesses tempos, foi proposta a criação de um "asylo de mendicidade", considerando-se de maior utilidade, convertê-lo em "pensionato de ensino profissional" (Souza 1875, p. 90), pois eram as condutas cotidianas das camadas populares, fugidias a qualquer instância normativa, que incomodavam e que se acreditava poder mudar com a educação para o trabalho. Dessa forma, nos moldes dos interesses da economia cafeeira, 
pretendia-se absorver formas tradicionais de vida, vistas como um entrave para a plena realização da riqueza, do progresso e da civilização.

Voltar-se principalmente para a infância dos segmentos populares fazia parte do esforço das elites de tentar formar um adulto acomodado às exigências do tempo e trabalhadores disciplinados para as lavouras.

Por isso, seus projetos, apresentados ao Governo e aos órgãos legislativos, previam a "criação de uma escola pública de instrução primária para meninos... e outra para meninas", dando-lhes conhecimentos de "utilidade real".

Assim, as meninas poderiam aprender "conhecimentos... mais delicados e conformes ao seu sexo", como os "trabalhos de agulha... lavar, engommar e cozinhar" (Souza 1875, p. 86), algo que também daria um fim prático às suas existências, livrando-as de um tempo livre que as elites associavam a todas as formas de vícios, quando nos meios populares ele poderia se inscrever no exercício fundamental da vivência coletiva.

Contudo, a utilidade era uma noção cara ao mundo burguês e capitalista que se erguia. Tudo competia para um fim prático e bem empregado, como 0 tempo, o lazer, a educação. Um bom emprego que priorizava a geração de riquezas, o que se mostraria, com o tempo, motivo de sérias conseqüências na visão de mundo e nas relações humanas, ressentidas com gravidade pelas sociedades atuais da época.

A educação agrícola funcionava também como um meio de os proprietários aprenderem a lidar com a liberdade da população cativa, e como uma forma de dirigirem essa liberdade para quadros de controle e estabilidade. Essas mesmas preocupações estender-se-iam aos libertos, ${ }^{12}$ pois acreditavam que sempre seguiam "o caminho da corrupção e isto [era] uma má circunstância contra os interesses sociais" (Congresso Agrícola 1878, p. 48).

Empolgavam-se com o exemplo vindo do Piauí, onde havia uma colônia fundada para educação dos libertos. Livrando-os da privação e da miséria, essa colônia certamente pouparia os proprietários de "bandos de criminosos", em que as pessoas poderiam se transformar em razão de sua falta de costume no trabalho (Souza 1875, p. 128).

Mas, num país essencialmente agrícola, o pergaminho seria a grande ambição dos barões do café para seus filhos, vaidosos de vê-los alcançar fortuna e posição com os graus conferidos pelo bacharelado em direito, preferencialmente, e depois pelas faculdades de medicina, farmácia, engenharia civil e militar, marinha, ordens sacras. 
Como bacharéis em direito, facilmente chegariam à posse dos altos cargos políticos do país, os quais suas famílias, em boa parte, já dominavam. Era uma forma de preservar a dignidade, acreditavam, não sujando as mãos em ofícios mecânicos e de lavradores, envergando um título que os levaria a cargos públicos de mando, favorecedores da exaltação e da personalidade individual.

Para os órfãos e os ingênuos, academias, sim, mas de agricultores, conferências populares e professores que discorressem sobre a faina com a terra, escolas práticas especiais de agricultura, onde, junto com o ensino elementar, teórico e prático, recebessem a "educação santa do trabalho".

Esse ensino "deveria estar ao alcance da lavoura para fornecer braços", catequizar os índios para torná-los "operários úteis à lavoura", parecendo oportuno também criar nas sedes das freguesias e capelas, as "Escolas de Domingo, atraindo a população da área rural, sob a direção dos párocos", já que, entendiam, essa população limitava-se a ir às povoações apenas seduzida "pelo sagrado engodo das festividades religiosas, que tão grande influência Ihe exerciam" (Souza 1875, p. 56).

A educação para a grande maioria da população brasileira priorizava os interesses da lavoura, desconsiderando a formação da pessoa. Tratavase de formar "braços" ou "operários", não seres sociais. Nesses caso, suas tradições e práticas de convívio, exercitadas em certas manifestações, como nas festas religiosas, eram vistas como impedimento para os intentos dos cafeicultores, desviando-os da condição de "operários".

Festas e jogos imbricavam-se à própria sobrevivência, nos meios pobres do passado e do presente. São momentos nos quais se urdem ajustes de trabalho e nos quais as ligações de amizade e parentesco se atam e reatam, viabilizando auxílios e acordos futuros.

"Bons operários" não deveriam viver de expedientes, de serviços apalavrados e de empregos provisórios. Sugeriam-se prêmios a quem conseguisse fixá-los nas propriedades, em trabalhos absorventes, desviandoos de uma convivência comunitária, incitadora de sentimentos e valores que conduziam a uma vida de arranjos em serviços de uns e outros.

"Bons operários" deveriam ainda conceber o ganho apenas sob os moldes do trabalho disciplinado e as ordens de alguém. Por isso a fúria combativa contra o hábito e as casas de jogo, proibindo-se alguns e todos aqueles outros "jogados a dinheiro", já que este só podia vir do trabalho que se defendia. ${ }^{13}$ 
A proposta educativa dos fazendeiros, nessa época, atrelava-se ainda à sugestão de criação de uma legislação penal relativa a ociosos, vagabundos, menores abandonados, impondo-Ihes penas severas e criando colônias em regime disciplinar, capaz de fazê-los adquirir hábitos de trabalho específicos. ${ }^{14}$

Outros ritmos de vida e trabalho, em desacordo com as exigências das lavouras e das propriedades, eram criminalizados, de modo a justificar a elaboração de leis rígidas e de espaços de confinamento e exclusão social.

Com o escravismo sendo a base das relações de trabalho na sociedade brasileira, pelo menos nas regiões de monocultura agroexportadora do sul e do sudeste, coube aos trabalhadores livres criar formas de sobrevivência que se fundaram, em boa parte, nos laços sociais que os unia, entre si, com proprietários mais ou menos abastados, com os próprios cativos.

Uma complexa microeconomia dos negócios, ${ }^{15}$ envolvendo uma infinidade de atividades, articulava-os em compromissos morais e de trabalho, fazendo deste último algo muito distante das disciplinas requeridas pelas grandes propriedades.

Como se poderia ser bem-sucedido nos negócios de carpintaria, de sapataria, de ferraria, de pequenas plantações, sem ser conhecido e bem afeiçoado em meio à vizinhança em que se vivia? Para tanto, o costume das visitas recíprocas, as festas religiosas, o mutirão, as vendas e os jogos eram espaços fundamentais para se aprimorar essa convivência imprescindível à sobrevivência.

Contudo, para os proprietários, esses modos de vida não passavam de ociosidade, fruto da "falta de correcção e polícia" que moralizassem e sujeitassem ao trabalho. Criticavam o hábito da gente pobre, livre e escrava, de andar de casa em casa, o que para eles não passava de pretexto para comer e levar uma vida estéril (Congresso Agrícola 1878, p. 47). Incompreendiam o sentido do costume da visita, em muitas situações, como compromisso moral e forma de estreitar os laços entre vizinhos e parentes, algo fundamental em um meio pobre no qual somente o viver junto amaciava as asperezas da sobrevivência cotidiana.

Para a elite agrária, que se acomodava ao capitalismo industrial e a suas prerrogativas, como fornecedora de bens da terra, o olho do estrangeiro incomodava, levando-a a desejar assemelhar-se aos europeus o quanto fosse possível. 
Para tanto, viam a necessidade de imprimir novas direções a hábitos profundamente arraigados, interferindo nos modos de vida e no trabalho da população. Era uma maneira de tornarem o país uma nação civilizada européia nos trópicos. Contudo, esse projeto envolveu esforço quase estéril, tal a habilidade das camadas populares em contornar as instâncias normativas.

Do ocidente a elite tirou formas de inspiração no vestir, no uso de objetos e utensílios, na música, na remodelação urbana, nas leituras e no trabalho. Os instrumentos agronômicos exigiam reformas, mas havia quem sugerisse que deveriam ser iguais aos da Prússia, tida como um dos "paizes mais adiantados da Europa" (Congresso Agrícola 1878, p. 147).

O exemplo do governo dos Estados Unidos na direção do ensino público era atraente aos olhos de uma elite ciosa de assemelhar-se ao estrangeiro, $e$ pensadores de fora do país eram os referencias para a instrução pública das crianças, como Jules Simon, Leon Faucher, Miguel Chevalier, Philibert Pompeo (Souza 1875, p. 68).

Era da Prússia, da Bélgica, da Holanda e dos Estados Unidos que ambicionavam que viessem professores habilitados, com conhecimentos da "agricultura teórica e prática e de todas as sciencias técnicas que [tivessem] relação com ela" (Souza 1875, p. 90).

O crescimento populacional e as facilidades de sua mobilidade, graças à evolução nos transportes, com o vapor e a ferrovia, o que encurtou as distâncias, de acordo com as condições do tempo e a libertação gradual dos escravos, deixavam um problema para os senhores do café: o que fazer com um número alarmante de gente sem recursos, tão racialmente diversificada e com modos de organizar a vida que incompreendiam? Como desenvolver uma ética do trabalho que, além de atender às exigências da lavoura, pudesse conter o potencial criminoso que acreditavam existir nas camadas populares? Acenava-se com a educação agrícola para a resolução desses problemas.

O compromisso transitório costurado pelas elites cafeeiras migrou das preocupações com o trabalho para as preocupações de ordem social, já que sempre lidavam com cativos e livres pobres, desconfiadas de suas inclinações rebeldes.

Socorreram-se, assim, nas propostas educativas, que além de visarem à preparação de trabalhadores com qualidades mais convenientes às lavouras e ao mundo cafeeiro de então, também previam sua imunização contra conseqüências incalculáveis de modos próprios de viver. 
No mais, os apelos do tempo exigiam que a noção de trabalho fincada com o colonizador e reforçada com a escravidão também mudasse, incumbindo-se disso a educação. Quase surpreendente, se não fosse compreensível, ver as elites cafeeiras combatendo noções de trabalho fundadoras do seu pensamento e que prosseguiram nos dilatados quadros das funções públicas: a ambição do ganho e da posição fácil, conquistados sem sujar as mãos e sem esforço aturado.

Dessa forma, a educação para o trabalho preconizada atingia noções enraizadas até o limite da preservação de práticas e concepções que garantissem privilégios e posições adquiridas.

\section{Notas}

1. "O peixinho encantado". In: CASCUDO, Luís da Câmara. Contos tradicionais do Brasil. $11^{a}$ ed. Rio de Janeiro: 1998, pp. 100-103.

2. "Chronicas". Gazeta de Campinas. 4 de dezembro de 1873, pp.1-2.

3. Deputado Eufrazio de Toledo. Anais da Assembléia Legislativa Provincial de São Paulo, 1858, pp. 169-170.

4. Sobre a ação protelatória das elites em relação às medidas pela libertação gradual dos escravos e à criação de um arcabouço jurídico que mediasse as relações de trabalho livre, cf., respectivamente, Gebara 1986 e Lamounier1988. A renovação dos estudos sobre a escravidão e a ação autônoma, de resistência e informal, dos escravos nesse contexto vem sendo há pelo menos uma década bem burilada por estudiosos importantes. Cf. Chalhoub 1990; Lara 1988; Wissenbach 1998; Machado1987; Mattos 1998.

5. Ingênuos eram crianças que, ao nascer de mãe escrava, a partir da promulgação da lei de 28 de setembro de 1871, conhecida como a "Lei do Ventre Livre", eram consideradas livres, devendo, contudo, permanecer sob a tutela de senhores de suas mães até os 21 anos.

6. Para uma ampla discussão sobre a extensa historiografia que tratou do tema do aproveitamento do trabalhador livre nacional, ver o texto de minha autoria, "Cotidiano, trabalho e pobreza em tempos de transição: Campinas, 1850-1888". Cadernos CERU, nº 7, 1996, pp. 113-122. Anteriormente, em 1989, foi publicado um texto de Peter Eisenberg, numa coletânea em homenagem ao seu precoce falecimento, no qual ele discutia essa mesma historiografia, centrando-se principalmente em estudos clássicos sobre o tema e o período, como Paula Beigueilman, A formação do povo no complexo cafeeiro (1968); Warren Dean Rio Claro, A brazilian plantation system, 1820-1950 (1976); Florestan Fernandes, A integração do negro na sociedade de classes (1965); Octácio lanni, Raças e classes sociais no Brasil (1966), entre outros. Cf. Eisenberg 1989.

7. Anais da Assembléia Legislativa Provincial de São Paulo, 22 de fevereiro de 1855, pp. 25-30.

8. Deputado Francisco Antonio de Mello Franco. Anais da Assembléia Legislativa Provincial de São Paulo, 22 de fevereiro de 1855, pp. 25-30. 
9. Sobre os modos de vida tradicionais, relacionados à obtenção dos meios de vida, cf. Cândido 1956.

10. Trata-se do Congresso realizado no Rio de Janeiro, com assistência do Ministério da Agricultura. Em contestação a esse encontro que os deixou de fora, os fazendeiros do nordeste promoveram algo semelhante, no mesmo ano, no Recife. Suas falas estão registradas numa publicação fac-similar comemorativa. Trabalhos do Congresso Agrícola do Recife. Recife: Fundação Estadual de Planejamento Agrícola de Pernambuco, outubro de 1878.

11. Existe uma vasta bibliografia sobre o tema da imigração européia para o Brasil, no contexto da transição para o trabalho livre. Ver, entre outros: Alvim 1986; Vangelista 1991

12. Libertos eram os escravos que de algum modo conseguiam sua liberdade, por cartas de alforria.

13. Código de posturas da Câmara Municipal de Campinas, Typ. Campineira, janeiro de 1864, p.14.

14. Idem, p. 67.

15. Cf. Moura 1998.

\section{Coffee and education in the century XIX}

ABSTRACT: Proposed educational they occupied cafeicultores and public authorities in the second half of the century XIX. With the crisis in the slavery relationships, they insisted in the need of her to be educating the poor and free men and the former-slaves for the work. They worried mainly about children, They proposed the creation of agrilcultural schools schools to educate them in the work disciplined in the great properties. The tensions, the limits and consequences of this movement for the social and human relationships are discussed in this text.

\section{Bibliografia}

ALVIM, Zuleika M.F. Brava gente: Os italianos em S. Paulo, 1870-1920. $2^{\underline{a}}$ ed. São Paulo: Brasiliense, 1986.

CÂNDIDO, Antonio. Parceiros do Rio Bonito: Estudo sobre o caipira paulista $e$ as transformações dos seus meios de vida. $2^{\underline{a}}$ ed. São Paulo: Nacional, 1956.

CASCUDO, Luís da Câmara. Contos tradicionais do Brasil. $11^{\underline{a}}$ ed. Rio de Janeiro: Ediouro, 1998.

CASTRO, Vicente Felix. Mistérios da roça. Guaratinguetá: Typ. Comercial, 1861.

CHALHOUB, Sidney. Visões da liberdade: Uma história das últimas décadas da escravidão na corte. São Paulo:Companhia das Letras, 1990. 
CONGRESSO AGRíCOLA. Colecção de Documentos. Rio de Janeiro: Typ. Nacional, 1878.

DEAN, Warren, Rio Claro. A Brazilian plantation system, 1820-1920. Stanford University Press, 1976.

EISENBERG, Peter L. Homens esquecidos: Escravos e trabalhadores livres no Brasil, sécs. XVIII e XIX. Campinas: Ed. da Unicamp, 1989.

FERNANDES, Florestan. A integração do negro na sociedade de classes. São Paulo: Dominus/USP, 1965.

GEBARA, Ademir. O mercado de trabalho livre no Brasil (1871-1888). São Paulo: Brasilense, 1986.

HOBSBAWM, E. A era do capital: 1848-1875. Trad. Luciano Costa Neto. $2^{2}$ ed. Rio de Janeiro: Paz e Terra, 1979.

HOLANDA, Sérgio Buarque. Raízes do Brasil. $23^{\underline{a}}$ ed. Rio de Janeiro: José Olympio, 1991a.

. História geral da civilização brasileira. $6^{\underline{a}}$ ed. Rio de Janeiro: Difel, 1991b, tomo II, vol. 3.

. História geral da civilização brasileira. $4^{\underline{a}}$ ed. Rio de Janeiro: Difel, tomo II, vol. 5 .

(org.). A herança colonial - Sua desagregação. História geral da civilização brasileira. Rio de Janeiro: Difel, 1993, tomo 2, vol. 1.

IANNI, Octávio. Raças e classes sociais no Brasil. Rio de Janeiro: Civilização Brasileira, 1966.

LAMOUNIER, Maria Lúcia. Da escravidão ao trabalho livre (a lei de locação de serviços de 1879). Campinas: Papirus, 1988.

LARA, Silvia Hunold. Campos da violência: Escravos e senhores na capitania do Rio de Janeiro, 1750-1808. Rio de Janeiro: Paz e Terra, 1988.

MACHADO, Maria Helena P.T. Crime e escravidão: Trabalho, luta e resistência nas lavouras paulistas, 1830-1888. São Paulo: Brasiliense, 1987.

MATTOS, Hebe Maria. Das cores do silêncio: Os significados da liberdade no sudeste escravista. Brasil, séc. XIX. $3^{a}$ ed. Rio de Janeiro: Nova Fronteira, 1998. 
MOURA, Denise A. Soares. "Cotidiano, trabalho e pobreza em tempos de transição. Campinas: 1850-88". Cadernos CERU, n 7, 1996, pp. 113122.

. Saindo das sombras: Homens livres no declínio do escravismo. Campinas:CMU/Fapesp/Unicamp, 1998.

PIRES, Cornélio. Conversas ao pé do fogo. São Paulo: Imesp, 1987.

PRADO Jr., Caio. Formação do Brasil contemporâneo. $7^{a}$ ed. São Paulo: Brasiliense, 1963.

SOUZA, João Cardoso Menezes. Theses sobre colonização do Brazil. Rio de Janeiro: Typ. Nacional, 1875.

VANGELISTA, Chiara. Os braços da lavoura: Imigrantes e "caipiras" na formação do mercado de trabalho paulista (1850-1930). Trad. Thei Almeida V. Bertorelli. São Paulo: Hucitec/Instituto Italiano di Cultura/ Instituto Cultural Ítalo-Brasileiro, 1991.

WISSENBACH, Maria Cristina Cortez. Sonhos africanos, vivências ladinas: Escravos e forros em S. Paulo (1850-1880). São Paulo: Hucitec/História Social/USP, 1998. 